\title{
Project Learn: Encouraging Innovation and Professional Growth through Classroom Research
}

\section{Kate Brooks}

Los Medanos College

\section{Introduction}

Classroom research in community colleges is an idea whose time has come. It offers a potentially powerful tool for informing faculty of who their students are, how they learn best and what teaching strategies are most effective. When undertaken by a group of faculty together and focused on the goal of instructional redesign, it encourages and supports classroom innovation.

Classroom research is, of course, not a new phenomenon. It has been going on for as long as concerned teachers have sought feedback from their students. What may be new is the idea that the instructor should become an avid, systematic researcher of the teaching/learning process in his or her classroom. The goal is not to formulate general rules, but to gain specific insights into how to teach a particular subject to a particular group of students more effectively. Demographics indicate that the sociological mix in our classrooms will only become more diverse, yet expectations of what teachers should accomplish are rising; in this atmosphere a tool that

From To Improve the Academy: Resources for Student, Faculty, and Institutional Development, Vol. 7. Edited by J. Kurfiss, L. Hilsen, S. Kahn, M.D. Sorcinelli, and R. Tiberius. POD/New Forums Press, 1988. 
aids in the improvement of individual learning experiences should be especially welcomed.

Faculty can be revitalized by refocusing their attention on how students learn; in a sense, they become students again themselves. After many years of teaching, faculty often lose the habit of seeking student evaluations, and may find threatening the thought of reviving a student evaluation process. Undertaking a classroom research project can cut through this lethargy and fear and re-ignite a spark of curiosity. By asking students to help in determining how they learn in specific situations, the evaluation process can be lifted above subjective judgments of how "good" or "bad" a teacher is. It opens a new type of dialogue in which both teachers and students share the realization that there are many different kinds of learners and many reasons for student success or failure beyond how "good" or "bad" the student is. Instructors have felt the classroom atmosphere tangibly improve once students understood the spirit and goals of Project Learn.

\section{Origin and Design of Project Learn}

Project Learn grew out of a partnership between an astronomy instructor (the author) and the learning specialist in language arts at our college. Curious to learn why the introductory astronomy course was so difficult for some students, the learning specialist sat in on one class session. She commented afterward, "I didn't understand a single thing you said." The instructor swallowed hard, but it was information she needed to hear. Surely the learning specialist wasn't alone, even among students who had been attending from the beginning of the course. It was clear the instructor had much to learn.

Thus began an ongoing program of investigating the factors that affect success for the groups of students who make their way through introductory astronomy. The initial focus on cognitive skills specific to astronomy later widened to include learning styles, motivation, situational and physical factors, and a host of skills, attitudes, and habits related to the learning process. Rather than searching the literature for generalizations about how these factors relate to success, the learning specialist and instructor decided to let the program evolve on its own, guided by the students and their own best sense of what to do next. The two initial steps were clear: first, they would learn more about the skills, learning styles, and habits of the students and the skills required by the subject. Second, they would incorporate that understanding into the revision of teaching strategies, with the aim of improving learning. 
As the program has evolved over two years, it has passed through three major phases, from initial exploration to full-blown implementation of seven grant-supported "research and redesign" projects involving ten percent of our faculty. The final phase drew faculty from a wide range of disciplines-history, social science, biology, astronomy, English literature, computer science, and math - and involved introductory-level courses meeting general education or A.A. degree requirements. None of the participating faculty were experienced in formal educational research, and the research approach throughout has been exploratory, actionoriented, and collectively planned and conducted. A cohesive spirit characterized the group, due in part to previous involvement in staff development programs and the strong tradition of interdisciplinary curriculum development and in-service training which has distinguished Los Medanos College from its inception.

After reviewing the exploratory stages, the following section presents findings from the research projects focusing only on students in the astronomy course. A description of the design and implementation of the expanded grant project follows. The final section discusses the limitations and significance of the results and explores the future development of this kind of project.

\section{Phase I. Pilot Study (Spring and Fall 1986)}

For two semesters, the learning specialist and the astronomy instructor conducted research on 110 students who took introductory astronomy. The approach was to identify skills and factors affecting success, assess students for these factors, and compare the results with final grades. An understanding of the learning-related factors that discriminated between high and low achievers could then be used to guide the revision of teaching strategies.

\section{Procedures and Results: First Semester}

During the first semester, 46 students, responding to a questionnaire, identified factors affecting their success in the course. At the end of the semester, the learning specialist developed a profile of "the student who succeeds in astronomy" through interviews with the instructor, the peer tutor, and a student group of five high achicvers (earning final grades of A or B) and five low achievers (earning final grades of D or F). She also gave a battery of standard tests to the small group of high and low achievers, assessing them for verbal and broad cognitive ability, reason- 
ing and visual skills. Ability in visual tasks might be important in astronomy, with its emphasis on visual subject matter.

Results showed that motivation, reasoning and verbal ability were high in all of the $A / B$ students and low in almost all of the D/F students. Notable exceptions were that two D/F students scored high in reasoning, and one scored high in verbal ability. In a surprising reversal of our expectations, all the D/F students, but only one A/B student, scored high on the test for perceptual speed in visual tasks. The instructor, the peer tutor, and both student groups all noted the same characteristics of successful students: (a) good study and notetaking skills, (b) attendance, (c) ability to visualize, observe and "put it all together," and (d) persistence in keeping up with the work. These initial results, revealing student focus on factors other than cognitive abilities and a lack of correlation between grades and cognitive abilities in notable individual cases, led next to an exploration of a broader range of success factors.

\section{Procedures and Results: Second Semester}

In the second semester, the learning specialist developed and administered to 64 astronomy students a new instrument, the "Self-Assessment: Learning Profile," which posed questions in each of the following categories:

(a) motivation, attitudes, and values

(b) situational factors (job, family responsibilities)

(c) background in math and science

(d) physical factors

(e) study skills, attitudes

(f) verbal skills

(g) learning style orientation (instructor, peer, self)

(h) learning style modality or mode (visual, auditory, tactile-kinesthetic)

(i) learning style: hemisphericity (right or left brain dominance)

(j) accessing skills

(k) processing skills

(l) expressing skills

She assessed 46 students for learning style modality with a second instrument, "The Learning Style Inventory" (Nikhazy/Stein), which separates the visual mode into verbal and nonverbal styles (Nikhazy and Stein, 1986). The verbal/nonverbal distinction in the visual mode may be important in astronomy, in which spatial visualization is a key skill. The learning specialist also audited one full unit (three weeks) of the course for first-hand observation of how the above factors operated in the classroom and course assignments. 
Comparison of final course grades with student responses on the above assessments yielded the following results. Grades showed no relation to student motivation and expectations in taking the course. (Research in the previous semester showed, in contrast, that motivation was different in high and low achievers; in that case, however, students responded to questions about motivation after receiving the final grade.) Grades also showed no relation to the frequency with which situational factors (job, family responsibilities, and workload in other courses) interfered with the accomplishment of course tasks. On the other hand, grades showed a definite relation to the following:
(a) grades earned in previous math and science courses
(b) the number of previous math and science courses taken
(c) study skills
(d) vocabulary and writing skills
(e) preference for studying alone (strongest in A students)
(f) willingness to ask questions in class
(g) notetaking ability
(h) preference for essay over multiple choice tests (stronger for A stu- dents)
(i) comfort in giving oral reports (greater for students earning higher grades)

Two factors were important for all students, regardless of grade earned: physical problems and difficulty in listening to lectures longer than 30 minutes.

Trends also emerged from the data on student learning styles. " $A$ " students showed a slightly stronger preference for the visual verbal and tactile-kinesthetic modes but a slightly weaker preference for the auditory mode than students who earned lower grades. More importantly, forty percent of all students tested had a dominant mode (so defined as having the score for one mode exceed the others by at least the average of the standard deviations for all modes). Twenty-seven percent of the students tested showed a strong preference for the visual mode, twenty percent preferring the visual nonverbal mode in particular. With respect to hemisphericity, "left-brained" students averaged slightly higher grades than "right-brained" students. The grade point average was 2.4 for students with a strong left dominance and one-half a letter grade lower (1.9) for right-dominant students.

\section{Conclusions from Phase I}

A few clear results emerged as guidelines for future revision of strategies. Breaking up lectures longer than 30 minutes with participatory 
exercises and activities would help one-fourth to one-half of the students in the class. Addressing physical problems with more sensitivity would also help at least one-fourth of the students. Both classwork and homework could be modified to accommodate students who prefer to study with friends. Poor performers might benefit from reinforcement of study and notetaking skills and practice in "pulling it all together" in essay questions. At Los Medanos College, the peer tutoring program offers the best avenue for skill reinforcement for poor performers, although they would also benefit from a classroom climate that better stimulates and maintains their interest and encourages them to ask questions. Clearly, at least one-fourth of the students (those with a dominant visual learning mode) might learn more easily if provided with visual aids.

\section{Phase II. Data Collection in Additional Courses and Design of Classroom Research Process (Spring 1987)}

With a bank of data now growing, and strategy revisions emerging from our study, it was time to tell others of the results and invite them to participate. Six additional faculty members chose to join the two researchers and apply for a POD grant to fund research projects in their courses. Receipt of the grant was of enormous help at this time, for it provided funds to hire student research assistants for data tabulation and to offer small stipends to participating faculty. In a semester devoted to planning, the group collected data in additional courses and met bi-weekly to discuss the implications of the data for improvement of instruction and the ways each participant planned to implement the research process.

\section{Additional Data Collection}

Most faculty chose to research student learning styles, in particular, the learning mode or the "Kolb" learning style (Kolb, 1984). Interest in the Kolb style arose partly because special teaching strategies existed that targeted each type (McCarthy, 1980; Samples, Hammond and McCarthy, 1985).

One hundred fifty-nine students, in one math and three science courses, took learning mode assessments. Of these, 88 preferred to learn through one or two dominant modalities. Calculations of mean grades for students with the same dominant modality yielded the results shown in Table 1. While mean grade differences between the modes are not im- 
pressive, two trends found earlier repeat themselves: auditory learners earn lower grades (at least in science and math courses), and most students are visual learners, specifically in the nonverbal mode. Students who had two outstanding preferred modes earned the highest mean grades, except where neither of those two modes was visual-verbal or auditory. The numbers were not large enough to render this result significant, however.

A strong relationship existed between grades and the Kolb Learning Styles. In Kolb's formulation, people take in information primarily through concrete experience (CE) or abstract conceptualization (AC).

\section{TABLE 1}

Mean Grades for Students of Different Learning Style Modes

\begin{tabular}{lcc}
\hline Mode & $\begin{array}{c}\text { Number of } \\
\text { Students }\end{array}$ & $\begin{array}{c}\text { Mean Grade } \\
(\mathbf{4}=\mathbf{A}, \mathbf{3}=\mathbf{B}, \mathbf{2}=\mathbf{C}, \mathbf{1}=\mathbf{D}, \mathbf{0}=\mathbf{F})\end{array}$ \\
Visual Verbal & 12 & $3.17 \pm 1.19$ \\
Visual Nonverbal & 48 & $2.88 \pm 1.73$ \\
Auditory & 9 & $2.50 \pm 1.42$ \\
Visual Tactile-Kinesthetic & 10 & $3.10 \pm 0.99$ \\
Visual Nonverbal/Auditory & 5 & $3.60 \pm 0.55$ \\
Visual Verbal/ & & $3.75 \pm 0.50$ \\
Visual Nonverbal & 4 & $2.50 \pm 1.52$ \\
Visual Nonverbal/ & & $4.00 \pm 0.00$ \\
Visual Tactile Kinesthetic & 6 & $3.00 \pm 1.41$ \\
Visual Verbal/Auditory & 1 & \\
Visual Verbal/ & & \\
Visual Tactile Kinesthetic & 2 & \\
\hline
\end{tabular}

TABLE 2

Mean Final Grades for Students of Different Kolb Learning Styles

\begin{tabular}{lcc}
\hline Kolb Type & $\begin{array}{l}\text { Number of } \\
\text { Students }\end{array}$ & $\begin{array}{c}\text { Mean Grades } \\
(4=\mathbf{A}, 3=\mathbf{B}, \mathbf{2}=\mathbf{C}, \mathbf{1}=\mathbf{D}, \mathbf{0}=\mathbf{F})\end{array}$ \\
Diverger & 22 & $2.46 \pm 1.14$ \\
Assimilator & 49 & $3.67 \pm 2.10$ \\
Converger & 11 & $3.55 \pm 2.50$ \\
Accommodator & 14 & $1.92 \pm 1.50$ \\
\hline
\end{tabular}


Processing styles range from reflective observation (RO) to active experimentation (AE). Combining accessing and processing styles yields four learning types: (a) divergers, who combine concrete experience with reflective observation, (b) assimilators, who combine reflective observation with abstract conceptualization, (c) convergers, who combine abstract conceptualization with active experimentation, (d) accommodators, who combine active experimentation with concrete experience (Kolb, 1984).

Ninety-six students in astronomy, intermediate algebra, anatomy/physiology, and literature courses took assessments for the Kolb style. Styles related to final grades, as shown in Table 2. The results clearly indicate that students who learn best through logical reasoning (assimilators and convergers) earn the highest grades, which is hardly surprising considering the stress on cognitive skill mastery in our educational system. Forty percent of all students do not learn best through lectures about concepts. Reaching all students requires that, at least in part, an instructor present material through concrete, personalized experiences and discussion of value questions.

\section{The Five-Step Research Process}

Learning style assessments were the first level of research in Project Learn, whose ultimate goal was improvement of instruction. The plan of action for translating the initial research findings into redesigned instruction involved in a five-step process, which can be summarized by posing the essential question each step sought to answer:

Step 1. How do the students learn?

Step 2. What do they need to know or be able to do to succeed in a particular unit of instruction?

Step 3. How and how well does the instructor currently teach the selected unit?

Step 4. How should the instructor redesign the unit?

Step 5. Do the redesigned strategies work better?

The specific tasks of each step were as follows:

Step 1. Assess students, the course tutor, the research assistant and the instructor for any or all of the following: (a) Kolb learning style, (b) learning modality (visual verbal and nonverbal, auditory, tactile-kinesthetic), (c) learning style orientation (instructor, self, tutor), (d) hemisphericity, (e) situational and physical factors, (f) other student characteristics. (Although not all faculty chose to focus on learning style, all gave at least one assessment to help build the data base.) 
Step 2. Select a unit in the course and, with the help of a fellow instructor and/or the student research assistant, identify factors leading to student success in mastering the course material. Focus might be on one or more of the following: (a) proficiency in the cognitive skills required by the discipline, (b) other skills assumed, consciously or unconsciously, by instructor assignments and behavior, (c) other student characteristics that have impact on learning success: motivation, skills in accessing, processing and expressing.

Step 3. Analyze and evaluate current teaching methods in the unit. Students, as well as the course tutor and/or research assistant should be active participants.

Step 4. Redesign and teach a unit that incorporates the finding in Steps 1-3.

Step 5. Evaluate student learning in the redesigned unit and compare the results with evaluations in the original unit (in a control section in either the same or a previous semester). Measures of improved learning should be grades on unit tests and assignments and student questionnaire responses.

\section{Phase III. Implementation of Seven Faculty Projects (Fall 1987)}

Faculty from seven disciplines implemented "research and redesign" projects the following semester. Instructors in social science (American Institutions and Ideals), Biology and Health, Introduction to Computer Science, and U.S. History all devised strategies to teach visual learners more effectively. More successful development of the thinking skill of "synthesis" was the goal in projects in a literature course and, again, in the U.S. History course. Astronomy and algebra instructors revised methods to follow the Kolb cycle and target each Kolb type in turn. The learning specialist served as a consultant, advising other faculty on redesign of classroom methods to accommodate students of different learning styles.

In monthly meetings participating faculty reported to each other on their progress and discussed the selection of units for redesign, relevance of the learning style data, self-evaluation of their teaching methods and the development of new strategies. Faculty members also met in pairs for more in-depth mutual consultation on lesson design and, in several instances, visited each other's classes to observe the revised strategies at work.

Table 3 summarizes the seven projects: course title, number of students and course sections, learning style elements assessed, units selected 
TABLE 3

Summary of Individual Faculty Projects

\begin{tabular}{|c|c|c|c|c|c|c|c|}
\hline \multirow[b]{2}{*}{ COURSES } & \multicolumn{3}{|c|}{$\begin{array}{l}\text { I. PROJECTS ACCOMMODATING } \\
\text { VISUAL LEARNING STYLES }\end{array}$} & \multicolumn{2}{|c|}{$\begin{array}{l}\text { 11. PROJECTS FOCUSING ON A } \\
\text { SPECIFIC THINKING SKILL } \\
\text { (SYNTHESIS) }\end{array}$} & \multicolumn{2}{|c|}{$\begin{array}{c}\text { III. PROJECTS } \\
\text { ACCOMMODATING KOLB } \\
\text { LEARNING STYLES }\end{array}$} \\
\hline & SOCIAL SCIENCE & $\begin{array}{l}\text { BIOLOGY \& } \\
\text { HEALTH }\end{array}$ & $\begin{array}{l}\text { INTRODUCTION } \\
\text { TO COMPUTERS }\end{array}$ & U.S. HISTORY & LITERATURE & $\begin{array}{l}\text { INTERMEDIATE } \\
\text { ALGEBRA }\end{array}$ & $\begin{array}{l}\text { INTRODUCTION } \\
\text { TO ASTRONOMY }\end{array}$ \\
\hline SECTIONS & 3 & 2 & 2 & 3 & 1 & 1 & 2 \\
\hline NO. OF STUDENTS & 89 & 42 & 65 & 75 & 13 & 26 & 44 \\
\hline $\begin{array}{l}\text { ST्ड़ Q } \\
\text { Assessments } \\
\text { Given } \\
\end{array}$ & Modality & $\begin{array}{l}\text { Modality } \\
\text { Hemisphericity }\end{array}$ & Modality & Modality & $\begin{array}{l}\text { Modality, Kolb } \\
\text { Hemisphericity }\end{array}$ & Modality, Kolb & $\begin{array}{l}\text { Modality, Kolb } \\
\text { Hemisphericity }\end{array}$ \\
\hline $\begin{array}{l}\text { इक्टीज \& } \\
\text { Unit Selection }\end{array}$ & Electoral College & $\begin{array}{l}\text { Communicable } \\
\text { Diseases }\end{array}$ & $\begin{array}{l}\text { Storage Devices } \\
\text { \&. File Processing }\end{array}$ & $\begin{array}{l}\text { Civil War } \\
\text { Reconstruction } \\
\text { Period } \\
\end{array}$ & Poetry & $\begin{array}{l}\text { Graphing } \\
\text { Quadratic } \\
\text { Equations }\end{array}$ & $\begin{array}{l}\text { Sun \& Stars: } \\
\text { Life Cycle of a Star }\end{array}$ \\
\hline $\begin{array}{l}\text { STE } 3 \\
\text { Current } \\
\text { Methods }\end{array}$ & Straight lecture & $\begin{array}{l}\text { Straight lecture } \\
\text { with visual aids } \\
\text { (overheads) }\end{array}$ & Straight lecture & Straight lecture & $\begin{array}{l}\text { Lecture ! } \\
\text { Discussion }\end{array}$ & $\begin{array}{l}\text { Lecture; Group } \\
\text { Homework \& in- } \\
\text { class problems }\end{array}$ & $\begin{array}{l}\text { Lecture } \\
\text { Audio tape / slides }\end{array}$ \\
\hline $\begin{array}{l}\text { STEjo A } \\
\text { Nature of } \\
\text { Revision }\end{array}$ & $\begin{array}{l}\text { Increased utiliza- } \\
\text { tion of visual aids }\end{array}$ & \begin{tabular}{|l|} 
Group work; \\
student presenta- \\
tions of content; \\
use of color-coded \\
cards, posters
\end{tabular} & $\begin{array}{l}\text { Group work; } \\
\text { visual mapping of } \\
\text { chapter; student } \\
\text { oral presentations }\end{array}$ & $\begin{array}{l}\text { Pontrayal of } \\
\text { Civil War condi- } \\
\text { tions by guest } \\
\text { actor; use of film } \\
\text { strips, videos }\end{array}$ & $\begin{array}{l}\text { Varied participa- } \\
\text { tory activities to } \\
\text { develop ability to } \\
\text { synthesize and } \\
\text { appreciate a } \\
\text { poem's full mess- } \\
\text { age }\end{array}$ & $\begin{array}{l}\text { Inclusion of ex- } \\
\text { amples from life; } \\
\text { fun, practical } \\
\text { applications }\end{array}$ & $\begin{array}{l}\text { Group work on } \\
\text { stellar evolution; } \\
\text { personalized ap- } \\
\text { proach to stars }\end{array}$ \\
\hline $\begin{array}{l}\text { STEP } \\
\text { Evaluation of } \\
\text { Learning In the } \\
\text { Revised Unit } \\
\text { by Student } \\
\text { Grades }\end{array}$ & $\begin{array}{l}\text { One-half a letter } \\
\text { grade improve- } \\
\text { ment }\end{array}$ & $\begin{array}{l}\text { Whole letter grade } \\
\text { improvement }\end{array}$ & $\begin{array}{l}\text { No grade differ- } \\
\text { ence }\end{array}$ & $\begin{array}{l}\text { Whole letter grade } \\
\text { improvement }\end{array}$ & $\begin{array}{l}\text { One-half a letter } \\
\text { grade improve- } \\
\text { ment }\end{array}$ & $\begin{array}{l}\text { Final exam ques- } \\
\text { tion scores on } \\
\text { revised material } \\
\text { one whole letter } \\
\text { grade higher than } \\
\text { exam scores on } \\
\text { unrevised unit }\end{array}$ & $\begin{array}{l}\text { Whole letter grade } \\
\text { improvement }\end{array}$ \\
\hline
\end{tabular}


for redesign, original and revised strategies and grade differentials as a measure of learning improvement.

In six out of the seven projects, grades were higher in the experimental section (or part of the course), in one case by as much as one-and-ahalf letter grades. Students evaluated revised methods by questionnaire also. They generally reported positive experiences, many noting that the more usual lecture classes hindered their learning. In particular, many reacted positively to the more varied methods employed in our experiments - small group work, hands-on learning, dramatic presentations, visual aids and others. In one notable exception, a small group mapping exercise, student reaction was not generally positive and grades did not improve. In retrospect, the instructor felt that students were inadequately prepared, both for the change and the particular group assignment given.

Four faculty members noted an improved climate, even a greater sense of bonding, in the class after the experiment. One noted, "The classroom atmosphere was markedly more spirited." Another instructor commented, "There is no question that the strategy worked. The visual aids and dramatization have obvious appeal and enhanced student interest level and morale."

\section{Interpretation of Results}

\section{Effectiveness of Specific Strategies}

Did Project Learn faculty accommodate learning styles and teach the skill of synthesis more effectively? Grades and student questionnaires in most cases definitely reflected improved learning, but careful interpretation of the results is necessary. Other factors clearly came into play.

The effect of change itself probably enhanced student attentiveness and response. Even when faculty did not announce to their classes that they were trying something new, instructors felt that they were either more organized than usual or subtly conveyed a sense of anticipation and enthusiasm. One way or another, students realized that something different was happening, which may have made them more open to learning. One instructor noted, "Students felt more interested because I was doing all this testing and experimenting."

Faculty were often aware of significant differences between the experimental and control sections or units. Even though comparison of grades on similarly taught units should theoretically compensate by measuring "intrinsic" differences, questions nevertheless remained about 
the validity of the controls. Students in the experimental literature class were generally more skilled and enthusiastic than the previous semester "control" students and averaged a whole letter grade higher in final course grades. They had a greater sense of rapport, perhaps due to field trips and out-of-class activities. The algebra instructor also questioned the validity of the controls, since performance on different material was compared. Faculty noted a number of additional factors that might have influenced results, such as time of day, "chemistry" of classes, length of class sessions, and proportion of different learning types. Faculty awareness of such issues is actually a benefit of this type of on-site research, where practitioners can isolate factors affecting the results.

In several cases, the redesign involved more than one change in strategy, and the data cannot clearly separate the effects of each. Multiple strategy revisions occurred in all experiments targeting visual learners. In the social science and history courses, more time was spent on the unit, although this was true for all sections. The experiments in biology and computer science introduced small group activities, thereby addressing both the sociological and modality elements of learning style. A visual mapping exercise in the computer science course involved a rather sophisticated technique, new to most students.

If proving the effectiveness of strategies which accommodate learning styles were the only goal, Project Learn was not a definite success. Improved learning occurred, but the reasons are not clear. A deeper analysis of the data on grades may yield more insights. Only one instructor, for instance, determined mean grades for students identified by learning style. On the open-ended, follow-up questionnaire not all faculty were comfortable asking for names or social security numbers of students. Thus, in most cases, the questionnaire responses cannot be analyzed by learning style groups, but only for the class as a whole.

Faculty reluctance to have students identify themselves highlights another limitation of this type of research, or at least an aspect that must be handled sensitively. Ethical questions arise in the minds of the faculty regarding student privacy and the unequal treatment of different sections. This is probably an unavoidable phenomenon when the instructor is also the researcher, and each practitioner must decide if the final goal of improved learning for the majority is worth the present risk of sacrificing improved learning for some.

\section{Effectiveness in Encouraging Faculty Development}

Did the project stimulate innovation and professional growth among the faculty? In this goal, the project was an unqualified success. Positive 
effects noted by participating faculty were the sense of discovery and excitement in trying new methods, a readiness to continue innovating, and the sense of trust and bonding in the group that arose from mutual support and assistance. Faculty noted also a greater awareness of (a) the many factors affecting learning, (b) the need for greater organization and efficiency in the classroom, (c) their unconscious expectations of students, and (d) the importance of learning styles - both the instructor's and the students'. One participant found the project "fun, stimulating, and useful," even if the results were not apparently positive. Another commented that she wanted to "re-examine and reshape" methods "thanks to the impetus of Project Learn."

All participating faculty chose to continue the process, and others expressed interest in future involvement. Four participants extended the new methods to at least one additional unit, and two stated their intention of revising an entire course. For one, "Project Learn started a process for me... I will continue to revise units in all my classes." One instructor immediately carried out a second project - researching the effectiveness of different testing methods - and then revised testing procedures in an entire course.

All seven faculty expressed the desire to study future classes, five of them in the next academic year. Five also hoped to continue meeting as a group. One instructor commented, "The opportunity to share curriculum as well as creative approaches to teaching is a real treasure." Eight additional faculty indicated an interest in implementing research projects, and five other colleges have requested presentations about Project Learn.

\section{Future Development of Classroom Research}

Several lessons from Project Learn should guide the implementation of classroom research in the future. First, such work definitely engages faculty, enhances their understanding of the learning process and encourages them to continue trying new methods. Second, faculty find it satisfying to see significant results. For this reason, project directors and participants should carefully design and monitor projects to achieve clear results. Third, faculty benefit from working together as a collaborative team. Mutual support sustains motivation, and each participant draws from the creativity of several minds in redesigning instruction and interpreting results. Faculty jointly "own" all phases of the project, from conception to implementation to interpretation. Engaging together in the expanded role of teacher-as-researcher promotes new norm-building and reinforces key values in the profession. Fourth, it is a great help to have 
grant support, not so much for financial reasons, but for assistance in data compilation and as an incentive to follow through and complete the projects. Faculty at our college are involved in many extra-teaching responsibilities which drain their precious time and energy. The recognition and impetus offered by a formal grant definitely helped to move the project along.

If interest in classroom research continues to gain momentum, faculty developers must find ways to expand experimental efforts such as Project Learn into on-going programs involving larger numbers of faculty. Grant support will probably be necessary both to inform faculty about what is involved and then to engage and support them in fruitful projects. If enough faculty find the results interesting and the effort worthwhile, they may begin to develop the research "habit." When the next generation of instructors comes along, classroom research can become an integral part of in-service training programs. In this way, a new role will evolve for instructors - that of researchers who constantly examine the interplay of teaching strategies, subject matter, and learner characteristics. The process can only enhance and deepen their understanding of what they really do as teachers.

\section{References}

Kolb, D. (1984). Experiential learning: Experience as the source of leaming and development. Englewood Cliffs, N.J.: Prentice-Hall.

McCarthy, B. (1980). The 4MAT system. Barrington, IL: Excel, Inc.

Nikhazy, N. and Stein, J. (1986). Leaming Style Inventory. Unpublished.

Samples, B., Hammond B., and McCarthy, B. (1985). 4Mat and science. Barrington, IL: Excel, Inc.

\section{Notes}

1. The author and participating faculty would like to acknowledge gratefully the grant from POD which partially funded the work of Project Learn.

2. Faculty participating in the POD grant project were: Kate Brooks (Instructor of Physical Science), Diane Downie (Instructor of Mathematics), Pat Gregorio (Instructor of Language Arts), Don Kaiper (Instructor of Social Science), Barbara Mahler (Instructor of Computer Science), Nancy Nikhazy (Learning Specialist in Language 
Arts), Carmen Rodriguez (Instructor of Social Science) and Mary Jo Starsiak (Instructor of Biological Science).

3. The author would like to thank Pat Gregorio for assistance in editing the manuscript. 